\title{
Effect of Feeding Regimes on Measurements of Carcass Dimensional and Proximate Composition of Blackhead Ogaden Sheep
}

\author{
Fasil Negussie ${ }^{1}$, Mengistu Urge ${ }^{1}$, Yosef Mekasha' ${ }^{2}$, Getachew Animut ${ }^{3}$ \\ ${ }^{1}$ School of Animal and Range Science, Haramaya University, Dire Dawa, Ethiopia \\ ${ }^{2}$ International Livestock Research Institute, Addis Ababa, Ethiopia \\ ${ }^{3}$ Agricultural Transformation Agency, Addis Ababa, Ethiopia \\ Email: ${ }^{*}$ fasiln27@gmail.com
}

Received 3 June 2015; accepted 24 June 2015; published 29 June 2015

Copyright $@ 2015$ by authors and OALib.

This work is licensed under the Creative Commons Attribution International License (CC BY). http://creativecommons.org/licenses/by/4.0/ (c) (i) Open Access

\begin{abstract}
A study was conducted with the objective to assess the effects of feeding regimes on carcass measurements and proximate composition of finishing Blackhead Ogaden (BHO) sheep. Twenty-four lambs with mean initial body weight of $17.3 \pm 0.52 \mathrm{~kg}$ were blocked into 6 groups of four lambs based on weight. Lambs in each block were randomly assigned to one of the four dietary treatments. During the growth phase, natural grass hay was offered ad libitum and a mixture of Acacia albida and Cactus pear (Opuntia ficus-indica) (at the ratio of 2:1, respectively) was supplemented at the rate of $0.9 \%$ (0.9ACM (acacia-cactus mixture), 1.2\% (1.2ACM) and 1.5\% (1.5ACM) of lambs body weight. Lambs in control treatment (OACM) did not receive the supplement. During the finishing phase, roughage composed of natural grass hay and haricot bean hauls at 50:50 ratio and concentrate supplement composed of $69 \%$ wheat bran and $31 \%$ oil seed meals (noug and cottonseed cakes at the ratio of 1.1:1) were fed at roughage (R) to concentrate (C) ratios of 60R:40C, 50R:50C, 40R:60C, and 30R:70C. The percentages of roughage and concentrate were determined based on ad libitum consumption of individual animal on dry matter (DM) basis. After the completion of stall feeding, all animals were slaughtered for carcass compositions and linear measurements evaluation. Except the anterior buttock circumference (ABC) and chest depth, all carcass measurements did not vary ( $p>0.05$ ) due to feeding regimes. Lambs fed 1.5ACM/30R:70C had (p $<0.05$ ) wider ABC than other treatment groups. Similarly, greater chest depth was recorded for groups in 1.5ACM/ 30R:70C than 0ACM/60R:40C, but the values for the rest treatments were similar. Most carcass compositions did not affect as a result of different feeding regimes, but fat content followed a similar trend to that of chest depth.
\end{abstract}

\section{Keywords}

Feeding Regimes, Compositions, Linear Measurements, Carcass, Sheep

"Corresponding author.

How to cite this paper: Negussie, F., Urge, M., Mekasha, Y. and Animut, G. (2015) Effect of Feeding Regimes on Measurements of Carcass Dimensional and Proximate Composition of Blackhead Ogaden Sheep. Open Access Library Journal, 2: e1589. http://dx.doi.org/10.4236/oalib.1101589 


\section{Introduction}

In the developing countries of Africa several production bottle necks hamper efficient ruminant animal production. Feed scarcity as well as high cost of feed is among the major factoring growth and carcass development [1]. In Ethiopia, there are about 28.5 million sheep [2], playing an important role in the country's economy through foreign currency earnings from export of life animal, meat, and leather and leather products and by their significant contribution to the livelihood of farmers by serving as a cash and animal origin protein source. However, due to several production constraints, carcass yield per sheep is rarely more than $10 \mathrm{~kg}$ [3] [4]. Moreover, the carcass measurement and conformation are also assumed to be low. Carcass dimensions give information on its development and help to determine the main assessment indices of carcass. Studies regarding the main sizes of carcasses are numerous and different [1] [5] [20] [21], in terms of anatomic reference points and in the measurements of indices. In the case of meat production, carcasses with large dimensions, have well developed hindquarter and carcass with medium to high lengths are the most preferred one by meat industry [5]. Earlier work, [6] reported that carcass conformation was an important indicator of commercial value since carcasses with better conformation was assumed to have advantages in terms of lean content, proportion of higher price cut and possibly greater muscle area. On the other hand, [7] suggested that the carcass composition determined the meat yield and meat sensorial characteristics. Thus, carcass economic value is based on its conformation and composition. Some of the inevitable confounding production variables in the comparison of measurements of carcass are sex, production systems (intensive vs. extensive rearing), feeding level or management. Researches so far conducted in Ethiopia have not produced information with regard to how different feeding regimes could affect composition and linear measurements of sheep carcass. The objective of this study was, therefore, to assess carcass compositions and dimensions of Blackhead Ogaden sheep maintained under different feeding regimes.

\section{Materials and Methods}

\subsection{Experimental Animals and Their Management}

The experiment was conducted at Haramaya University goat farm $\left(9.0^{\circ} \mathrm{N}\right.$ latitude and $42.0^{\circ} \mathrm{E}$ longitude). A total of 24 Blackhead Ogaden lambs with age of 8 - 10 months, as estimated by dentition and information obtained from the owners, were purchased from Jijiga market. Experimental animals were quarantined for 3 weeks in isolated holding yards at the university and vaccinated against common infectious diseases in the area (pasteurellosis and anthrax), de-wormed against internal parasites by albendazol de-wormer, and sprayed with acaricides (Vetacidin 20\%) against external parasites. Following quarantine, the experimental animals were placed in experimental house partitioned into individual pens $(70 \times 120 \mathrm{~cm})$ that is equipped with feeding trough and watering bucket. Animals were acclimated to the experimental procedures and feeds for 14 days before the commencement of the trials. The experiment consisted growth and finishing phases each with three months of stall feeding Afterthe completion of 180 days stall feeding, all lambs were slaughtered for carcass linear measurements and compositions studies.

\subsection{Experimental Feeds}

\subsubsection{Growth Phase}

Natural grass hay as a basal diet and dried Acacia albida leaves and pods, and Cactus pear cladodes mixed (ACM) at the ratio of 2:1 as a supplement were used during the three months of growth phase. Fresh Acacia albida leaves and Cactus pear cladodes were collected from plants in Haramaya University campus. Fresh leaves of the Acacia were harvested from available trees regardless of the plants age, trimmed with its pods, spread thinly on plastic sheet under shade and turned regularly to ensure uniform drying for safe storage. Likewise, the cactus cladodes were hand chopped into pieces or strips to an approximate size of $5 \mathrm{~cm}$ for ease of feeding and drying and spread thinly on plastic sheet under shade and dried. 


\subsubsection{Finishing Phase}

The same natural pasture hay used during growth phase and haricot bean haulms mixed in the ratio of 50:50 were used as a basal diet during the finishing phase [8] and [9]. Haricot bean haulms of different varieties were obtained from the University's crop research and production section. The roughages were separately chopped by hand tool to a length of approximately $5 \mathrm{~mm}$ for simplicity of mixing and to reduce selection by animals. The supplement feed comprised wheat bran, noug and cotton cake meals. Concentrate ingredients were mixed at the ratio of $69 \%$ wheat bran and $31 \%$ of oil seed meals (noug and cotton seed meals in 1.1:1 ratio). The roughage and the concentrate feeds were offered in a separate feeder.

\subsection{Experimental Design and Treatments}

The lambs were blocked into six groups based on initial body weight. Lambs in a block were randomly assigned to one of the four dietary groups making a total of six lambs in each group. Thus, a randomized complete block design (RCBD) was employed. The initial body weight of the experimental animals was determined by two consecutive weighing after overnight withdrawal of feed and the average of the two days were taken. After the completion of the growth experiment, the animals were used for finishing phase with no change of groups.

During the growth phase, the treatments were based on the amount of dried Acacia albida leaf and pod and Cactus pear cladodes mixture supplement at the ratio of 2:1, respectively. The level of supplement feeding was at the rate of 0ACM (the control groups did not get any supplement, only the basal diet), 0.9ACM (Supplementation with Acacia albida and Cactus pear cladodes mixture at a rate of $0.9 \%$ body weight), 1.2ACM and 1.5ACM. Hay was offered ad libitum at $20 \%$ refusal rate. Treatments during the finishing phase were different proportions of roughage (R) to concentrate (C) ratio, which included 60R:40C, 50R:50C, 40R:60C, and 30R: 70C. The proportion of roughage to concentrate was determined from animals' ad libitum intake on dry matter basis, which was adjusted every four days. In both phases feed was offered in two equal meals.

\subsection{Carcass Compositions and Linear Measurements}

After the completion of stall feeding, all experimental animals were fasted overnight with access to water and then slaughtered. The dressed carcass of each lamb was chilled at $4^{\circ} \mathrm{C}$ in a refrigerator for $24 \mathrm{hrs}$. Cold carcass was suspended with hind legs on hock gambre of constant width $(20 \mathrm{~cm})$ and the following carcass linear measurements were recorded using tape in centimeter. Carcass length (from the basis of the tail to the basis of the neck), hind leg length (the smallest distance of the tarsal-metatarsal articular surface), anterior and posterior buttock circumference of thorax (measured horizontally around the buttock at the level of the maximum width of the trochantor and the caudal insertion, respectively), chest depth (from the sternum to the thoracic vertebra), and buttock and shoulder width (at the level of the scapula from one lateral surface to the other). Thereafter, the cold carcass was split in to two equal halves along the dorsal mid-line using a hand saw. The left half of each carcass was dissected into lean, fat, bone and used to estimate the whole composition.

\subsection{Chemical Analysis}

Samples of feed offered, refusals, and feces were ground to pass a $1 \mathrm{~mm}$ sieve mesh kept in air tight plastic bags pending analysis. DM, OM, and Nitrogen $(\mathrm{N})$ were determined according to the procedures of previous work [10]. The crude protein content was estimated as $N \times 6.25$. Organic matter $(\mathrm{OM})$ was calculated as the difference between 100 and ash content. Neutral detergent fiber (NDF), Acid detergent fiber (ADF) and Acid detergent lignin (ADL) were analyzed according to the procedures used in earlier studies [11].

\subsection{Statistical Analysis}

The data subjected to Analysis of Variance (ANOVA) using the general linear model procedure of [12]. Treatment means were separated using Tukey HSD (Tukey honestly significant difference) test. The model for data analysis was $Y_{i j}=\mu+T_{i}+B_{i}+E_{i j}$. Where, $Y_{i j}$ is the response variable; $\mu$ is the overall mean; $T_{i}=$ the treatment effect; $B_{i}$ is the block effect and $E_{i j}$ is the random error. 


\section{Results and Discussion}

\subsection{Chemical Composition of Feeds}

The CP content of the natural pasture hay is at the borderline of minimum CP needed for maintenance requirements of ruminant animals while NDF and ADF were high (Table 1). Acacia albida has high CP content while cactus cladode is characterized by its low CP content. The hay contains the minimum (7\%) CP needed to support acceptable ruminal microbial activity and the maintenance requirement of the host ruminant [13]. The CP content of A. albida was within the range of $12 \%$ - 18\% reported by previous workers [14] and [15]. Cactus pear contains low CP than hay and the value obtained in the present study is comparable to that reported in earlier studies [16] [17]. Fiber fractions content was higher for the natural pasture hay than A. albida and Cactus cladodes. The fiber fractions content of A. albida is comparable to values of $560 \mathrm{~g} / \mathrm{kg}$ NDF and $336 \mathrm{~g} / \mathrm{kg}$ ADF reported earlier [18]. The CP content of hay used in the finishing phase is similar to that of growth phase, since the source is the same (Table 1). The CP composition of haricot bean haulm was relatively lower than hay. Low $\mathrm{CP}$ concentration in haricot bean haulm is attributed to late harvesting of the crop after much of the leaves have been shattered. As expected, the CP content of the concentrate mixture is well above required to satisfy the nitrogen demand for proper functioning of rumen microorganisms and it is a good complement to the low quality roughage used.

\subsection{Carcass Linear Measurements}

Treatment groups did not differ in carcass linear measurements, except for anterior buttock circumference (ABC) and chest depth (CD) (Table 2). Lambs fed with 1.5ACM/30R:70C have wider ABC than the rest treatment groups, while the CD is longer in 1.5ACM/30R:70C than 0ACM/60R:40C. According to earlier work [19], the linear carcass measurements are indices of skeletal development and indirectly help to determine carcass conformation. Effect of nutrition on carcass linear measures were reported earlier [1] [19] and generally confirmed that increased level of supplement improved most of the carcass linear measurements. In the present study, except $\mathrm{ABC}$ and chest depth values, most of the carcass linear measurements did not affected due to the different feeding regimes. Increasing level of supplement and proportion of concentrate during the growth and finishing

Table 1. Chemical composition of ingredients and experimental diets used during growth and finishing phases (DM as \%, others \%DM).

\begin{tabular}{|c|c|c|c|c|c|c|}
\hline \multirow{2}{*}{ Parameters } & \multicolumn{6}{|c|}{ Chemical composition } \\
\hline & $\mathrm{DM}$ & $\mathrm{OM}$ & $\mathrm{CP}$ & NDF & $\mathrm{ADF}$ & $\mathrm{ADL}$ \\
\hline \multicolumn{7}{|c|}{ Growth phase } \\
\hline Natural pasture hay & 90.7 & 90.0 & 7.8 & 67.6 & 33.2 & 21.5 \\
\hline Acacia albida & 91.2 & 89.8 & 12.0 & 52.5 & 32.0 & 9.80 \\
\hline Cactus cladodes & 90.3 & 82.0 & 5.99 & 23.3 & 15.0 & 2.40 \\
\hline 2Acacia:1Cactus & 90.7 & 84.7 & 11.0 & 35.7 & 21.5 & 4.20 \\
\hline \multicolumn{7}{|c|}{ Finishing phase } \\
\hline Natural pasture hay & 90.7 & 90.0 & 7.8 & 67.6 & 33.2 & 21.5 \\
\hline Haricot bean haulms & 91.3 & 90.1 & 6.7 & 62.1 & 38.9 & 7.00 \\
\hline Wheat bran & 89.2 & 85.9 & 17.7 & 39.5 & 11.6 & 2.10 \\
\hline CSM & 91.8 & 80.8 & 28.0 & 34.9 & 30.9 & 7.70 \\
\hline NSM & 91.0 & 89.2 & 40.0 & 41.9 & 15.2 & 8.30 \\
\hline Concentrate mixture & 90.5 & 85.0 & 18.5 & 39.1 & 17.4 & 6.70 \\
\hline
\end{tabular}

$\mathrm{DM}=$ Dry matter; $\mathrm{OM}=$ Organic matter; $\mathrm{CP}=$ Crude protein; $\mathrm{NDF}=$ Neutral detergent fiber; $\mathrm{ADF}=$ Acid detergent fiber; $\mathrm{ADL}=\mathrm{Acid}$ detergent lignin; CSM = cotton seed meal; NSM = noug seed meal. 
phases improved the circumference of anterior buttock and depth of the chest. This is in line with [20] who noted that almost all linear carcass measurements did not varied with the diet except buttock width which was higher for group of kids fed higher level of supplement diet. Contrary to this, [20] reported that lambs fed at high level of concentrate showed greater values for most of the linear measurement parameters. The average numerical value recorded for carcass length was comparable to that reported by [20], but was greater than the value reported by [1] [21], however, was lower when compared to 78 and $75 \mathrm{~cm}$ obtained for South African Merino and Durmer sheep [22]. The discrepancy in length might be due to differences in breeds of experimental animals and types feed used during the experimental periods. Chest depth was also increased with increased level of foliage supplements and concentrate proportion during the growth and finishing phases, respectively. Differences for these carcass linear measurements among the treatment groups showed a positive relationship with slaughter weight, since heavier lambs at slaughter attained greater carcass linear measurements [23].

\subsection{Carcass Composition}

Percentage of lean, bone, and meat to bone ratio was not impacted $(\mathrm{p}>0.05)$ by the different feeding regimes (Table 3). Percentage of fat content of the carcass was significantly $(p<0.05)$ higher in 1.5ACM/30R:70C groups than 0ACM/60R:40C. The major non genetic factor influencing carcass composition is nutrition. Accordingly, higher fat percentage of carcass of lambs fed higher level of concentrate is associated with higher muscular fat proportion due to intake and availability of essential nutrients. In concurrence with the present findings, other researchers also reported higher proportion of fat in lambs fed with higher concentrate ration than consumed lower concentrate containing diets [24] [25]. The result of the present findings, however, is in contrast

Table 2. Effects of different feeding regimes on carcass linear measurements.

\begin{tabular}{|c|c|c|c|c|c|c|}
\hline \multirow{2}{*}{ Parameters (cm) } & \multicolumn{4}{|c|}{ Dietary treatments ${ }^{*}$} & \multirow{2}{*}{ SEM } & \multirow{2}{*}{ p-value } \\
\hline & 0ACM/60R:40C & 0.9ACM/50R:50C & 1.2ACM/40R:60C & 1.5ACM/30R:70C & & \\
\hline Carcass length & 54.8 & 56.5 & 52.5 & 58.0 & 1.64 & 0.1468 \\
\hline Leg length & 32.7 & 34.0 & 33.3 & 33.3 & 0.96 & 0.9729 \\
\hline PBC & 49.5 & 50.3 & 55.0 & 49.2 & 1.44 & 0.0539 \\
\hline $\mathrm{ABC}$ & $36.9^{b}$ & $33.5^{b}$ & $36.7^{\mathrm{b}}$ & $42.5^{\mathrm{a}}$ & 0.58 & 0.0001 \\
\hline Buttock width & 11.6 & 11.8 & 12.8 & 11.5 & 0.76 & 0.6071 \\
\hline Shoulder width & 8.75 & 8.78 & 8.71 & 9.42 & 0.52 & 0.7500 \\
\hline Chest depth & $22.8^{\mathrm{b}}$ & $24.6^{\mathrm{ab}}$ & $24.5^{\mathrm{ab}}$ & $26.8^{\mathrm{a}}$ & 0.71 & 0.0153 \\
\hline
\end{tabular}

Means in a row with different superscript are significant at $\mathrm{p}<0.05$; PBC $=$ Posterior buttock circumference; ABC = Anterior buttock circumference; * Growth phase treatments are based on Acacia albida and Cactus pear cladodes mixture (ACM) supplementation at a ratio of 2 to 1 , respectively; $0 \mathrm{ACM}=$ no supplement, control; $0.9 \mathrm{ACM}=$ supplementation at a rate of $0.9 \%$ body weight; $1.2 \mathrm{ACM}=1.2 \%$ body weight; $1.5 \mathrm{ACM}=1.5 \%$ body weight, and finishing phase treatments are based on roughage (R) to concentrate (C) ratio: 60R:40C (60\% roughage and 40\% concentrate feeding); 50R:50C; 40R:60C; 30R:70C.

Table 3. Effect of different feeding regimes on the carcass compositions.

\begin{tabular}{ccccccc}
\hline \multirow{2}{*}{ Parameters } & \multicolumn{9}{c}{ Dietary treatments $^{*}$} & \multirow{2}{*}{ SEM } & p-value \\
\cline { 2 - 5 } & 0ACM/60R:40C & 0.9ACM/50R:50C & 1.2ACM/40R:60C & 1.5ACM/30R:70C & & \\
\hline Lean (\%) & 62.3 & 58.1 & 58.1 & 56.1 & 2.42 & 0.5417 \\
Bone (\%) & 22.5 & 26.7 & 21.2 & 20.6 & 1.96 & 0.1596 \\
Fat (\%) & $15.2^{\mathrm{b}}$ & $16.3^{\mathrm{ab}}$ & $20.6^{\mathrm{ab}}$ & $23.3^{\mathrm{a}}$ & 1.59 & 0.0085 \\
Meat: bone & 3.8 & 2.8 & 3.8 & 4.0 & 0.37 & 0.1412 \\
\hline
\end{tabular}

Means in a row with different superscript are significant at $\mathrm{p}<0.05 ;{ }^{*}$ Growth phase treatments are based on Acacia albida and Cactus pear cladodes mixture (ACM) supplementation at a ratio of 2 to 1, respectively; $0 \mathrm{ACM}=$ no supplement, control; $0.9 \mathrm{ACM}=$ supplementation at a rate of $0.9 \%$ body weight; $1.2 \mathrm{ACM}=1.2 \%$ body weight; $1.5 \mathrm{ACM}=1.5 \%$ body weight, and finishing phase treatments are based on roughage (R) to concentrate $(\mathrm{C})$ ratio: 60R:40C (60\% roughage and 40\% concentrate feeding); 50R:50C; 40R:60C; 30R:70C. 
with earlier studies [26] [27] who did not found significant differences between dissected lean, bone, and inter muscular fat weight or percentage of growing ram lambs fed with different proportion of roughages and concentrate. This could be attributed to the relatively good diets used in all treatment groups during the studies. The lack of significant difference for the value of bone in this experiment is that it is a tissue which develops early in all animal species and does not depend on nutrition and sex at older ages [28]. Feeding regimes also did not impact value of meat to bone ratio. In line with this, several authors have been reported that levels of supplement and feeding regimes did not affect meat to bone ratio for different indigenous breeds of sheep and their crosses [20] [21] [29] [30]. Differences amongst these studies might be due to a consequence of environmental effects, probably related to diet compositions, the degree of maturity attained at the slaughter body weight and breed differences.

\section{Conclusion}

The experiment was conducted to assess the effects of feeding regimes on the compositions and carcass linear measurements of Blackhead Ogaden sheep. The result of this study revealed that except the fat content which was greater for lambs fed 1.5ACM/30R:70C diet, all the carcass composition parameters did not impact due to the different feeding regimes. Moreover, sheep fed at higher level of foliage supplementation during the growth phase and higher proportion of concentrate during the finishing phase showed wider anterior buttock circumferences and longer chest depth.

\section{References}

[1] Eniolorunda, O.O., Apata, E.S. and Okubanio, A.O. (2011) Body and Carcass Measurements of Rams Fed Graded Levels of Biscuit Waste Based Diet. African Journal of Feed Science, 51, 333.

[2] CSA (Central Statistics Agency of Ethiopia) (2011) Agricultural Sample Survey. Volume II—Report on Livestock and Livestock Characteristics of Peasant Holdings. Statistical Bulletin, 505, 109.

[3] MOARD (Ministry of Agriculture and Rural Development) (2007) A Comprehensive Plan for Supporting the Meat Export Industry, 2007 (1999 EC), Prepared by Technical Task Force, Part-I. Ministry of Agriculture and Rural Development, Addis Ababa.

[4] Berhe, G. (2010) Animal and Plant Health. Directorate-Ministry of Agriculture and Rural Development of Ethiopia. Dialogue on Livestock, Food Security and Sustainability, a Side Event on the Occasion of the 22nd Session of COAG, FAO, Rome, 16 June 2010.

[5] Elena, I., Vasile, R., Diana-Patricia, R., Aurel, G., Calin, I., Stelian, D., Marilena-Gabi, N. and Constanta, S. (2010) The Index of Carcass Conformation at Young Sheep. Animal Science and Biotechnologies, 43, 310.

[6] Kempster, A.J., Cuthberston, A. and Harrington, G. (1982) The Relationship between Conformation and the Yield and Distribution of Lean Meat in the Carcasses of British Pigs, Cattle and Sheep. Meat Science, 6, 37-53. http://dx.doi.org/10.1016/0309-1740(82)90049-3

[7] Delfa, R. and Teixeira, A. (1998) Sheep Carcass Quality. In: Sheep Meat: Key Aspects, University Press c/coord, Buxadé Carlos Carbo, 373-400.

[8] Dejene, A. (2010) The Effect of Feeding Different Proportions of Maize Stover and Haricot Bean (Phaseolus vulgaris) Haulms Supplemented with Mixtures of Concentrate Diet on the Performance of Hararghe Highland Goats. M.Sc. Thesis, Haramaya University, Ethiopia.

[9] Emebet, L. (2008) Supplementation of Blackhead Ogaden Sheep Fed Haricot Bean (Phaseolus vulgaris) Haulms with Mixtures of Wheat Bran and Brewers Dried Grain: Effects on Feed Utilization, Live Weight Gain and Carcass Parameters. M.Sc. Thesis, Haramaya University, Ethiopia.

[10] AOAC (Association of Official Analytical Chemistry) (1990) Official Methods of Analysis. 15th Edition, Association of the Official Analytical Chemistry, Washington DC.

[11] VanSoest, P.J. and Robertson, J.B. (1985) Analysis of Forages and Fibrous Feeds: A Laboratory Manual for Animal Science, Vol. 613. Cornell University, Ithaca.

[12] SAS (Statistical Analysis System) (2008) SAS for Window, Release 9.1. SAS Institute, Inc., Cary.

[13] Van Soest, P.J. (1994) Nutritional Ecology of the Ruminant. 2nd Edition, Cornell University Press, London.

[14] Tesfay, Y. (2010) Feed Resources Availability in Tigray Region, Northern Ethiopia, for Production of Export Quality Meat and Livestock. Example from Selected Woredas in Tigray Regional State. Consultation Report Submitted to the Ethiopian Sanitary and Phyto-Sanitary Standards and Meat Marketing Program, 87 p. 
[15] Mousa, M.R. (2011) Effect of Feeding Acacia as Supplementation on the Nutrient Digestion, Growth Performance, Carcass Traits and Some Blood Constitutes of Awassi Lambs under the Conditions of North Sinai. Asian Journal of Animal Science, 5, 102-117. http://dx.doi.org/10.3923/ajas.2011.102.117

[16] Tikabo, G., Solomon, M. and Alemu, Y. (2006) Effect of Wilting Cactus Pear (Opuntia ficus-indica) on Feed Utilization of Sheep. Tropical Science, 46, 37-40. http://dx.doi.org/10.1002/ts.27

[17] Daniel, T., Solomon, M. and Yoseph, M. (2014) Effect of Supplementation of Cactus and Selected Browses Mix on Feed Utilization of Somali Goats. American Scientific Research Journal for Engineering, Technology, and Sciences, 9, 20-34.

[18] Weldegebriel, B., Kefelegn, K. and Mulat, H. (2014) Effect of Feeding Acacia Pods (Acacia seyal) with or without Wheat Bran on Feed Intake and Digestibility of Tigray Highland Sheep in Hay Based Feed. Journal of Biology, Agriculture and Healthcare, 4, 26-33.

[19] De Boer, H., Dumont, B.L., Pomeroy, R.W. and Weniger, J.H. (1974) Manual on E.A.A.P. Reference. Methods for the Assessment of Carcass Characteristics in Cattle. Livestock Production Science, 1, 151-164. http://dx.doi.org/10.1016/0301-6226(74)90055-4

[20] TsegayT., Mengistu U. and Yoseph M. (2012) Carcass Measurement, Conformation and Composition of Indigenous and Crossbred (Droper x Indigenous) F1 Sheep. Pakistan Journal of Nutrition, 11, 1055-1060. http://dx.doi.org/10.3923/pjn.2012.1055.1060

[21] Alexandre, G., Liméa, L., Nepos A., Fleury, J., Lallo, C. and Archimede, H. (2010) The Offal Components and Carcass Measurements of Creole Kids of Guadeloupe under Various Feeding Regimes. Livestock Research for Rural Development, 22, Article No. 100. http://www.lrrd.org/lrrd22/5/alex22100.htm

[22] Cloete, S.W.P., Olivier, J.J., du Tort, E. (2004) Linear Type Traits in a Merino Flock Subjected to Selection for Increased Clean Fleece Mass and an Unselected Control Flock. South African Journal of Animal Science, 22, 70-73.

[23] Abdullah, A.Y. and Qudsieh, R.I. (2008) Carcass Characteristics of Awassi Ram Lambs Slaughtered at Different Weights. Livestock Science, 117, 165-175. http://dx.doi.org/10.1016/j.livsci.2007.12.020

[24] Seethalakshmi, M.K., Sundaram, S.M., Kumarja, R., Sivakumar, T.,Gnanaraj, P.T. and Murugan M. (2008) Carcass Characteristics of Madras Red Lambs Fed Diets of Varying Level Forage and Concentrate. Journal of Veterinary Animal Science, 39, 10-13.

[25] Karim, S.A., Porwal, K. and Singh, V.K. (2007) Carcass Traits of Kheri Lambs Maintained on Different Systems of Feeding Management. Meat Science, 76, 395-401. http://dx.doi.org/10.1016/j.meatsci.2006.06.008

[26] Mahgoub, O.C. and Early, R.J. (2013) Effects of Dietary Energy Density on Feed Intake, Body Weight Gain and Carcass Chemical Composition of Omani Growing Lambs. Small Ruminant Research, 37, 35-42. http://dx.doi.org/10.1016/S0921-4488(99)00132-7

[27] Nagireddy, N.K., Yerradoddi, R.R., Micheal, B., Devanaboyina, N., Thamatam, M., Belum, V.S. and Chintalapani, R.D. (2012) Growth Performance and Carcass Characteristics of Growing Ram Lambs Fed Sweet Sorghum Baggase Based Complete Rations Varying in Roughage to Concentrate Ratios. Tropical Animal Health and Production, 44, 1717-1724.

[28] Solomon M and Simret (2008) Body Weight and Carcass Characteristics of Somali Goats Fed Hay Supplemented with Graded Levels of Peanut Cake and Wheat Bran Mixture. Tropical Animal Health Production, 40, 553-560.

[29] Birhanu, T., Getachew A. and Mengistu U. (2013) Effect of Green Prosopis juliflora Pods and Noug Seed Cake (Guizotia obissynica) Cake Supplementation on Digestibility and Performance of Blackhead Ogaden Sheep Fed Hay as a Basal Diet. Science, Technology and Arts Research Journal, 2, 38-47. http://dx.doi.org/10.4314/star.v2i2.98881

[30] Getahun, K. (2014) Effect of Concentrate Supplementation on Performances of Ethiopian Lowland Afar and Blackhead Ogaden Lambs. Animal and Veterinary Sciences, 2, 36-41. http://dx.doi.org/10.11648/j.avs.20140202.14 